\title{
Ewolucja instytucji dialogu społecznego w Polsce po 1989 roku
}

Wydawnictwo Sejmowe, Warszawa 2018, s. 227

\section{Evolution of the institution of social dialogue in Poland after 1989}

The reviewed book presents the process of developing and shaping the legal foundations of the functioning of the institution of social dialogue in Poland after 1989. The author discusses the evolution of the trilateral commissions. This process took place in the light of social and economic transformations powering its course. The essence of social dialogue is presented, with particular attention being paid to its situating in the Constitution of the Republic of Poland. The book explains the significance and points to the position of the institution of social dialogue in the economic system and the system of the state.

Słowa kluczowe: dialog społeczny, komisje trójstronne, partnerzy społeczni, współpraca

Key words: social dialogue, trilateral commissions, social partners, cooperation

W demokratycznym państwie prawnym prawo stanowione powinno pozostać w bezpośrednim związku z potrzebami społecznymi oraz problemami obywateli, którym ma służyć, i musi odpowiadać celowi, dla którego jest uchwalane, tzn. hominum causa omne ius constitutum sit (wszelkie prawo powinno być stanowione dla ludzi). Szczególne znaczenie mają w tym zakresie standardy partycypacji obywateli $\mathrm{w}$ procesie stanowienia prawa. Wypracowanie nowych i wykorzystywanie już istniejących mechanizmów komunikacji społecznej pozwala na prawidłowe rozpoznanie i realizację potrzeb społecznych. Jednym $\mathrm{z}$ takich mechanizmów obecnym w polskim porządku prawnym niemal od początku przemian ustrojowych są instytucje dialogu społecznego, których głównym celem jest dążenie do zachowania pokoju społecznego. Funkcjonowanie takich instytucji stanowi płaszczyznę porozumienia między partnerami społecznymi a przedstawicielami władzy. Uważa się, że taka konstrukcja instytucji dialogu społecznego przynosi efekty będące ważnym składnikiem tworzenia trwałej i spójnej wspólnoty naszego państwa. Wpływ instytucji dialogu społecznego na kształt polityki państwa jest ważkim tematem nie często podejmowanym w polskim piśmiennictwie. Niewątpliwie z tego też powodu książka A. Ogonowskiego jest pożądana. Ciekawa konstrukcja monografii oraz jej treść sprawiają, że opracowanie zasługuje na uwagę i wnikliwą lekturę. Jednak należy podkreślić, że tytuł opracowania Ewolucja dialogu społecznego w Polsce po 1989 roku może wprowadzać w błąd czytelnika poszukującego całościowego opracowania na temat dialogu społecznego w Polsce. Z uwagi na skromny komentarz poświęcony zagadnieniu dialogu społecznego określonego w preambule Konstytucji RP (szerokie rozumienie), tytuł monografii powinien brzmieć np. „Ewolucja instytucji dialogu społecznego statuowana w art. 20 konstytucji”, bowiem aktualna nazwa monografii wydaje się zbyt szeroka.

Jak wskazał autor: „Zakres niniejszej pracy obejmuje próbę kompleksowego omówienia procesu powstawania i formułowania prawnych podstaw funkcjonowania trój- 
stronnych instytucji dialogu społecznego w Polsce po 1989 r. oraz ich stopniowego ewoluowania wraz ze zmieniającymi się stosunkami społecznymi i gospodarczymi. W książce w sposób syntetyczny zaprezentowana jest idea dialogu społecznego, a w szczególności sposób i zakres jej konstytucjonalizacji. [...] Praca jest również próbą usytuowania instytucji dialogu społecznego w sferze ustroju gospodarczego oraz określenia ich relacji z organami władzy publicznej i władzy wykonawczej” (s. 8). Recenzowana monografia prezentuje ewolucje funkcjonujących w państwie ogólnokrajowych ciał trójstronnych, tj. Trójstronnej Komisji do Spraw Społeczno-Gospodarczych, działającej na podstawie uchwały Rady Ministrów nr 7/94 z dnia 15 lutego 1994 r. w sprawie powołania Trójstronnej Komisji do Spraw Społeczno-Gospodarczych, Trójstronnej Komisji do Spraw Społeczno-Gospodarczych, umocowanej w ustawie z dnia 6 lipca 2001 r. o Trójstronnej Komisji do Spraw Społeczno-Gospodarczych i wojewódzkich komisjach dialogu społecznego (Dz.U. z 2001 r. nr 100, poz. 1080) oraz działającej obecnie Radzie Dialogu Społecznego powołanej ustawą z dnia 24 lipca 2015 r. o Radzie Dialogu Społecznego i innych instytucjach dialogu społecznego (tekst jedn. Dz.U. z 2018 r. poz. 2232, ze zm.). Analiza pozycji ustrojowej instytucji dialogu społecznego jest wyjściowym fragmentem pracy. Autor podkreślił, że poszukując elementów konstytuujących pozycję instytucji dialogu społecznego, należy „[...] przeciwstawić się postrzeganiu jej jako wyłącznie organu opinio-konsultacyjnego Rady Ministrów” (s. 8). A. Ogonowski dowodzi, że ciało to odgrywa istotną rolę w wielu dziedzinach funkcjonowania państwa. Ma ono wpływ na kształt ustroju gospodarczego RP, reprezentuje oraz pozwala artykułować interesy grupowe, przez co znacznie wpływa na kształtowanie się jednolitego pojmowania idei dobra wspólnego.

Książka składa się z czterech rozdziałów tworzących spójny i logiczny układ. Przedmiotem rozdziału I jest m.in. konstytucjonalizacja dialogu społecznego w Polsce. Autor rozpoczyna swoje rozważania o instytucjach dialogu społecznego od prezentacji pojęcia dialogu społecznego w kompleksowym ujęciu. Przedstawia znaczenie dialogu społecznego z punktu widzenia różnych płaszczyzn, np. pojęcie dialogu w Konstytucji RP, pojęcie dialogu w prawodawstwie UE czy pojęcie dialogu społecznego w naukach społecznych (s. 9-31). Zabieg ten pozwala czytelnikowi rozeznać się w temacie, który będzie przewodził dalszym częściom monografii. Mając na uwadze konstytucyjne umocowanie dialogu społecznego, autor wskazał różne formy oddziaływania dialogu społecznego na wybrane normy Konstytucji RP (s. 32-49). A. Ogonowski odnosi się do relacji dialogu społecznego z zasadą demokratycznego państwa prawnego, zasadą państwa urzeczywistniającego zasady sprawiedliwości społecznej, zasadą pomocniczości oraz konstytucyjnym prawem do rokowań. Dalsze rozważania tego rozdziału nawiązuje do treści art. 20 konstytucji, zgodnie z którym ,społeczna gospodarka rynkowa oparta jest na [...] dialogu i współpracy partnerów społecznych”. Przepis ten przesądza o roli dialogu społecznego w funkcjonowaniu ustroju gospodarczego RP. Analiza powyższego zagadnienia wieńczy pierwszą część pracy A. Ogonowskiego (s. 49-72). W rozdziale II autor odniósł się do genezy Trójstronnej Komisji do spraw Społeczno-Gospodarczych (działającej na mocy uchwały Rady Ministrów). W rozważaniach uwzględnia instytucje dialogu społecznego 
przed 1989 r., czym w znaczący sposób podnosi walory swojej pracy (s. 73-79), dokonuje szczegółowego opisu instytucji dialogu społecznego w projektach konstytucyjnych oraz w pracach Komisji Konstytucyjnej Zgromadzenia Narodowego (s. 88-103). Prace te miały znaczący wpływ na to, aby Trójstronna Komisja do Spraw Społeczno-Gospodarczych znalazła umocowanie w akcie o randze ustawowej. Organizacja, skład i tryb pracy tej Trójstronnej Komisji przybliżone zostały w rozdziale III (s. 104-118). W tej części monografii autor opisał kompetencje (umocowanej w ustawie) Trójstronnej Komisji (s. 118-148), zwrócił uwagę na umiejscowienie Komisji w systemie organów władzy państwowej (s. 149-158) oraz przybliżył funkcje, jakie ona pełniła (s. 159-162). Wprowadzeniem do rozdziału IV książki jest odniesienie do przyczyn rozwiązania Trójstronnej Komisji do Spraw Społeczno-Gospodarczych (s. 163-171), które doprowadziło do powołania następcy prawnego o zwiększonych kompetencjach - Rady Dialogu Społecznego. W tej części pracy autor przybliżył sposób funkcjonowania (s. 172-181), kompetencje oraz funkcje rady (s. 182-193).

Wystarczy analiza samej struktury monografii, aby zauważyć, że instytucje dialogu społecznego w Polsce przeszły dużą transformację. O ile skład komisji trójstronnych na przestrzeni lat nie uległ znaczącej zmianie - skupiając w swoich szeregach przedstawicieli trzech stron: pracowników (zrzeszonych w związkach zawodowych), organizacji pracodawców oraz rządu - o tyle legitymizacja oraz zakres kompetencji instytucji dialogu społecznego uległy przekształceniom. Pierwsze lata działalności Komisji Trójstronnej charakteryzowały, oprócz słabej legitymizacji, mocno skonfliktowane, upolitycznione relacje między partnerami dialogu. Czynniki te doprowadziły do sytuacji, w której w szczytowych latach działalności Trójstronnej Komisji do Spraw Dialogu Społecznego (działającej na mocy uchwały Rady Ministrów) nie doszło do żadnego porozumienia stron. W rzeczywistości okazało się, że komisja służyła do „wygaszania" kryzysów, które co jakiś czas wybuchały między poszczególnymi podmiotami tej instytucji. Komisji nie udało się zbudować w strukturach władzy autonomicznej platformy do prowadzenia dialogu, ,[...] lecz została wchłonięta i zinstrumentalizowana przez system polityczny" (s. 194). Przyczyn słabej wydolności komisji można upatrywać w różnych źródłach, np. zgodnie z ówczesną opinią Komisji Europejskiej, Polska nie wypracowała (na tamten czas) jasnego podziału kompetencji między partnerami społecznymi a rządem w prowadzeniu dialogu społecznego. Do rzadkości należały także negocjacje z udziałem pracodawców prywatnych, ponieważ stronę pracodawców w komisji reprezentowali przedstawiciele przedsiębiorstw publicznych, co można było odczuć jako celowe pomijanie sektora prywatnego w pracach komisji. Usprawnienie działalności komisji nastąpiło w 2001 r., wraz z wejściem w życie ustawy o Trójstronnej Komisji do Spraw Społeczno-Gospodarczych. Lepsza legitymizacja komisji oraz zmiany, jakie wniosła ustawa w funkcjonowanie komisji, pozwoliły na stworzenie ,[...] forum dialogu społecznego, działającego bardziej efektywnie" (s. 195). Wyeliminowano z niej rozwiązania utrudniające prace poprzedniej komisji, m.in. ustalono czytelne kryteria powoływania składu instytucji, dzięki czemu była lepiej odbierana przez społeczeństwo, które nie bało się zaufać tworzącym ją partnerom 
społecznym. Mimo to zbyt duże organizacyjne i finansowe uzależnienie rządu doprowadziło do sytuacji, w której po kilku latach obowiązywania Trójstronnej Komisji do Spraw Społeczno-Gospodarczych przekształciła się ona w Radę Dialogu Społecznego. Obecnie funkcjonująca Rada Dialogu Społecznego jest wyposażona w zdecydowanie lepsze uprawnienia niż działające do tej pory komisje trójstronne. Partnerzy społeczni rady mogą m.in. opiniować projekty założeń do projektów ustaw oraz innych aktów prawnych, przygotowywać wspólnie uzgodnione projekty założeń ustaw i projekty innych aktów prawnych, występować ze wspólnymi wnioskami o wydanie lub zmianę ustawy albo innego aktu prawnego, wnioskować o przeprowadzenie wysłuchania publicznego. Rada Dialogu Społecznego uniezależniła się także od strony rządowej, m.in. poprzez możliwość korzystania z własnego budżetu, posiadania niezależnego biura. Rada została także zobligowana do przygotowania rocznego planu prac, co usprawniło i usystematyzowało jej działalność. Ważnym momentem z punktu widzenia funkcjonowania Rady było wprowadzenie w niej rotacyjnego przewodnictwa. A. Ogonowski słusznie zaznaczył, że w świetle zagwarantowanych usprawnień to od strony społecznej w przeważającej mierze zależy poziom aktywności, sprawności i skuteczności funkcjonowania Rady Dialogu Społecznego.

Kluczowe znaczenie w kontekście celu badawczego recenzowanej pracy ma próba systematyzacji konstytucyjnej instytucji dialogu społecznego oraz rozważania nad trójstronnym modelem tych instytucji. Autor przytoczył fragmenty ustawy zasadniczej w różny sposób odwołujące się do dialogu społecznego. Ustrojodawca we wstępie do konstytucji odnosi się do „dialogu społecznego”, art. 20 zaś stanowi o „dialogu i współpracy partnerów społecznych”. Mimo że oba fragmenty odnoszą się do dialogu, to w odmienny sposób należy je interpretować, co słusznie jest zaznaczone w recenzowanej monografii. Komisje trójstronne, o których mowa, stanowią platformę dialogu społecznego, określonego w art. 20 konstytucji, który dopuszcza dialog społeczny między różnymi grupami interesu funkcjonującymi w społeczeństwie obywatelskim. Natomiast dialog władzy z obywatelami, podejmowany w sprawie rozstrzygnięć w sferze publicznej, stanowi definicję pojęcia „dialogu społecznego" z preambuły konstytucji. A. Ogonowski zmierzył się z wyzwaniem rozstrzygnięcia dylematu głębszej konstytucjonalizacji instytucji dialogu społecznego. Problem ten od lat nie traci na znaczeniu, a już na etapie prac konstytucyjnych podnoszono postulaty bezpośredniej konstytucjonalizacji komisji trójstronnej. Na początkowym etapie prac Komisja Konstytucyjna odznaczała się nieprzychylnym stosunkiem do propozycji wysuwanych przez związki zawodowe. Temat instytucji dialogu społecznego powrócił dopiero pod koniec obrad nad nowym kształtem konstytucji, jak się okazało — zbyt późno. Prace na projektem ustawy zasadniczej były na tyle zaawansowane, że wprowadzenie rewolucyjnych modyfikacji było niemożliwe, stąd kompromisowe brzmienie art. 20 konstytucji, które nie powołuje nowego organu, ale umożliwia jego powołanie. Autor podkreślił, że brak bezpośredniego umocowania komisji trójstronnych w ustawie zasadniczej przesądził o jej niezbyt mocnej pozycji ustrojowej oraz mało sprecyzowanych funkcjach. Natomiast obecne w Konstytucji RP ogólne sformułowania dotyczące "dialogu społecznego" 
są gwarantem istnienia nieograniczonej liczby różnego rodzaju instytucji dialogu społecznego. A. Ogonowski zauważył, że takie uregulowanie pozwala na odejście od trójstronnej formuły instytucji dialogu społecznego na rzecz pluralistycznych formuł prowadzenia dialogu społecznego. Co w efekcie sprowadza się do tego, że autor nie postuluje ściślejszej regulacji konstytucyjnej instytucji dialogu społecznego. Trudno jednoznacznie odnieść się do tej opinii. Warto rozważyć, czy w świetle rosnącego znaczenia społeczeństwa obywatelskiego mocniejsze umocowanie bądź uwzględnienie w konstytucji uprawnień przewidzianych dla instytucji dialogu społecznego nie spowoduje skuteczniejszego i efektywniejszego działania tych instytucji.

Otwartość i elastyczność rozwiązań przyjętych przez ustrojodawcę w sprawie „dialogu społecznego" skłoniła autora do refleksji nad zmianą trójstronnej formy dialogu społecznego. Kształt instytucji dialogu społecznego obecny w Polsce jest typowy dla państw postkomunistycznych, co nie wydaje się dziwne w krajach Europy Środkowo-Wschodniej, które cechuje wspólny rdzeń w zakresie modelu społeczno-gospodarczego. Autor uważa, że w doktrynie obecne są głosy, jakoby to znaczenie dialogu społecznego podawane w konstytucji miało uprawdopodobnić wybór modelu korporacyjnego. A. Ogonowski jest jednak odmiennego zdania, słusznie skądinąd broniąc stanowiska, że „odwołanie do dialogu społecznego nie determinuje jednoznacznie modelu trójstronnego". Model korporacyjny przyjęty w Polsce odnosi się do funkcjonujących w państwie stosunków gospodarczych opartych na modelu industrialnym. Przyjmuje się, że trójstronny model instytucji dialogu społecznego stanowi ,[...] rewizję tradycyjnych założeń parlamentarnych demokracji politycznej poprzez jej wzbogacenie o elementy reprezentacji funkcjonalnej" (s. 199). Obrana przed laty formuła trójstronności była odpowiedzią na reformy prowadzone w państwie, np. realizację zadań związanych z prywatyzacją oraz restrukturyzacją. Ponadto przyjmowano, że obecność w instytucjach dialogu społecznego reprezentacji strony rządowej podmiotów reprezentujących pracowników i pracodawców prowadzących dialog między sobą gwarantowała zachowanie pokoju społecznego. Wnioski autora sformułowane w kontekście kształtu instytucji dialogu społecznego stanowią cenny wkład w dorobek doktryny w przedmiotowej materii. A. Ogonowski zakłada bowiem, że uzupełnienie trójstronnego dialogu korporacyjnego $\mathrm{w}$ dalszej perspektywie czasu będzie nieuniknione. W obliczu umacniających się struktur społeczeństwa obywatelskiego funkcjonujące w Polsce instytucje dialogu społecznego staną się bardziej otwarte na prowadzenie wielostronnego dialogu obywatelskiego, do którego dołączą reprezentacje społeczeństwa obywatelskiego, tj. samorządy zawodowe, samorządy gospodarcze, organizacje pozarządowe, reprezentujące interesy grup najsłabszych społecznie i ekonomicznie. Autor uważa, że instytucja aktywizująca społeczeństwo obywatelskie powinna powstać obok funkcjonującej Rady Dialogu Społecznego. Swój punkt widzenia uzasadnia wykładnią systemową konstytucji, w której rozdzielono dialog obywatelski (preambuła do Konstytucji RP) oraz dialog społeczny w sferze ustroju gospodarczego (art. 20 konstytucji). W opinii recenzenta przedmiotowej monografii, powstanie dwóch tworów o podobnej tematyce może utrudnić prowadzenie skutecznego i efektywnego dialogu. Tym bardziej, że można odnieść wrażenie, iż względy, na które 
wskazuje autor, przemawiają raczej za zmianą konstrukcji instytucji dialogu społecznego, niż za powoływaniem nowych instytucji czy dublowaniem już istniejących.

Przechodząc do ogólnej oceny monografii, należy zaznaczyć, że A. Ogonowski dobrze ocenia funkcjonowanie instytucji dialogu społecznego. Podobnie jak inni przedstawiciele doktryny zajmuje stanowisko, że polskie rozwiązania wykazują duży potencjał, aczkolwiek nie są one przestrzegane jako element nowej formuły organizacyjnej państwa i jego organów. Problematyka instytucji dialogu społecznego jest otwarta na nowe koncepcje doskonalenia tej formy zarządzania państwem i rozwiązywania konfliktów społecznych. Można przypuszczać, że w obliczu umacniania się znaczenia społeczeństwa obywatelskiego w państwie książka A. Ogonowskiego będzie stanowić ważne źródło wiedzy na temat instytucji dialogu społecznego.

Wioleta Wasil*

* Mgr Wioleta Wasil, Biuro Analiz Sejmowych Kancelarii Sejmu, wioleta.wasil@sejm.gov.pl, https://orcid.org./0000-0002-6286-1055 